JPdK Volume 3 Nomor 2 Tahun 2021 Halaman 30-41

JURNAL PENDIDIKAN dan KONSELING

Research \& Learning in Primary Education

\title{
Peran Pendidikan Kewarganegaraan bagi Generasi Milenial dalam Menanamkan Jiwa Nasionalisme Di Era Globalisasi
}

\author{
Daniar Asyari ${ }^{1}$, Dinie Anggraeni Dewi ${ }^{2}$ \\ Program Studi Pendidikan Guru Sekolah Dasar \\ Fakultas Keguruan dan Ilmu Pendidikan \\ Universitas Pendidikan Indonesia \\ Email: daniarasyari@upi.edu ${ }^{1}$, dinieanggraenidewi@upi.edu ${ }^{2}$
}

\begin{abstract}
Abstrak
Perkembangan ilmu pengetahuan dan teknologi akhir-akhir ini semakin modern yang menuntut moralitas dan tingkat nasionalisme yang tinggi, karena ilmu tidak memiliki tingkat nasionalisme dan moralitas yang tinggi, yang membawanya pada pendidikan khususnya PKn telah kehilangan keutamaannya sebagai wadah humanistik. Beberapa orang memiliki pengetahuan yang baik tentang kewarganegaraan dan prestasi yang baik, tetapi tidak memberikan manfaat di lingkungan komunitas bahkan telah menjadi penyakit komunitas itu sendiri. Hal itu membahayakan eksistensi budaya dan nilai-nilai kemanusiaan karena ruh Nasionalisme dan moralitas rendah. Dampak negatif globalisasi yaitu perilaku tidak etis yang dilakukan oleh anak usia sekolah. Melalui siaran televisi dan media massa, bagaimana anak itu membunuh ayahnya dan ibunya sendiri, pecandu narkoba, mabuk-mabukan, bunuh diri dan masih banyak lagi. Hal tersebut menunjukkan bahwa pendidikan selama ini belum menyentuh ranah kesadaran siswa.
\end{abstract}

Kata Kunci : Moralitas, Humanistik, Globalisasi

\begin{abstract}
The development of science and technology has recently become more modern which requires morality and a high level of nationalism, because science does not have a high level of nationalism and morality, which has led to education, especially Civics, which has lost its primacy as a humanistic vessel. Some people have good knowledge about citizenship and good achievement, but it does not provide benefits in the community environment and has even become a disease of the community itself. It endangers the existence of culture and human values because of the spirit of nationalism and low morality. The negative impact of globalization is unethical behavior by school-age children. Through television broadcasts and mass media, how the child killed his own father and mother, drug addicts, drunkenness, committed suicide and many more. This shows that education so far has not touched the realm of student awareness.
\end{abstract}

Keywords : Morality, Humanistic, Globalization 


\section{PENDAHULUAN}

Pembelajaran

pendidikan

kewarganegaraan pada dasarnya merupakan belajar tentang Indonesia. Artinya belajar menjadi orang Indonesia seutuhnya, yang mampu menumbuhkan rasa kebangsaan dan cinta tanah air Indonesia. Warga negara yang baik adalah seseorang yang berkepribadian Indonesia, rasa kebangsaan yang tinggi, mencintai pancasila dan Undang-Undang Dasar 1945, serta mencintai tanah air dan bangsa Indonesia. Sesuai dengan dinamika kehidupan, bermasyarakat, berbangsa, dan bernegara, nilai-nilai perjuangan rakyat Indonesia untuk merebut dan mempertahankan kemerdekaan mengalami pasang surut. Akibat pesatnya pengaruh perkembangan teknologi di era globalisasi, semangat perjuangan bangsa Indonesia kini semakin merosot pada titik kritis dan mengkhawatirkan.

Globalisasi yang disebabkan oleh pesatnya perkembangan ilmu pengetahuan dan teknologi, baik dibidang informasi, komunikasi dan transportasi telah menjadikan dunia semakin transparan, seolah-olah dunia telah menjadi struktur baru, yaitu struktur global. Hal ini tentunya sangat berdampak bagi Indonesia pada struktur kehidupan bermasyarakat, berbangsa dan bernegara. Semua ini akan sangat mempengaruhi pemikiran, mental, dan sikap generasi muda yang menjadi harapan generasi penerus bangsa. Terkait dengan hal tersebut, seluruh warga negara Indonesia, khususnya generasi muda Indonesia, perlu dibekali pendidikan kewarganegaraan dengan pemahaman kesadaran berbangsa dan bernegara secara baik dan dinamis, guna menumbuhkan sikap rela berkorban demi bangsa dan negaranya, serta menumbuhkan jiwa patriotisme yang luhur terhadap bangsa dan negara Indonesia. UndangUndang Nomor 20 tahun 2003 tentang Sistem Pendidikan Nasional mengatur tentang fungsi dan tujuan pendidikan nasional yang harus digunakan dalam proses pembinaan dan pembentukan karakter dan peradaban bangsa yang bermartabat.

Berdasarkan Undang-Undang pendidikan, pendidikan harus mencakup tiga hal, yaitu bimbingan, pengajaran dan pelatihan.
Bimbingan berarti mentransfer nilai, mengajar berarti mentransfer pengetahuan, dan pelatihan yaitu berfungsi pembentukan kepribadian. Pendidikan kewarganegaraan yang dilaksanakan sesuai predikatnya harus mampu menanamkan nilai-nilai kebangsaan dan tingkah laku yang harus dimiliki peserta didik, menjadi warga negara yang baik, dan mencintai tanah air, serta rela berkorban untuk kemaslahatan bangsa dan negaranya.

Sebagai bangsa yang beradab, tentunya kita tidak akan pernah melupakan peristiwa bersejarah 28 Oktober 1928, atau yang disebut dengan semangat "Sumpah Pemuda". Sumpah Pemuda mencerminkan semangat nasionalisme yang tinggi dari pemuda Indonesia yang merupakan generasi muda penerus bangsa. Namun kini, kita melihat terjadinya krisis dalam semangat nasionalisme pada generasi muda Indonesia. Semangat nasionalisme saat ini cenderung kasar, agresif bahkan brutal.

Sedangkan rancangan nasionalisme lama menjadi lebih ramah. Pada generasi muda juga terdapat sikap apatisme, seolah nasionalisme hanya tinggal kenangan, tidak perlu menengok kebelakang. Bahkan semangat nasionalisme pun dikalahkan oleh perkembangan globalisasi, yang sangat berpengaruh besar dalam kehidupan bernegara dan berbangsa, baik secara langsung maupun secara tidak langsung. Pengaruh perkembangan globalisasi akan mempengaruhi jiwa nasionalisme bangsa Indonesia khususnya generasi muda yang menjadi harapan generasi penerus bangsa.

Upaya Pendidikan Kewarganegaraan harus diberi kekuatan untuk berkreasi bagi generasi milenial dalam kehidupan sehari-hari. Hal tersebut untuk meningkatkan budi pekerti, dari segi budaya sopan dan santun, menghargai proses, dan daya juang yang harus dibiasakan dan dibina. Hal ini bertujuan untuk memberikan landasan bagi bangsa dan negara untuk membina generasi muda yang cerdas dan baik, sehingga dapat berpartisipasi secara aktif dan efektif dalam kemerdekaan untuk masa depan yang lebih baik. Sehingga tercipta generasi muda yang berkualitas dan berkarakter, serta menjadikan Indonesia yang lebih baik. 
Pendidikan Kewarganegaraan berorientasi menumbuhkan konsep status bangsa, dan juga bersifat implementatif dalam kehidupan seharihari. Adapuncita- cita yang ingin dicapai setelah pengajaran pendidikan kewarganegaraan itu, akan ada generasi milenial yang bisa menjaga keutuhan dan persatuan bangsa. Adapun fungsi Pendidikan Kewarganegaraan antara lain :

1. Membantu generasi milenial memahami cita-cita nasional sebagai tujuan bangsa.

2. Generasi milenial dapat mengambil keputusan yang bertanggung jawab dalam menyelesaikan masalah pribadi, komunitas, dan nasional.

3. Dapat menghargai cita-cita bangsa dan dapat mengambil keputusan yang bijak.

4. Dengan membina kebiasaan berpikir dan bertindak sesuai dengan tugas pancasila dan Undang-Undang Dasar Negara Republik Indonesia Tahun 1945, membentuk warga negara yang cerdas, terampil dan khas serta setia pada bangsa dan negara Indonesia.

\section{METODOLOGI PENELITIAN}

Metode Penelitian Online (ORM)
merupakan cara bagi peneliti untuk
mengumpulkan data melalui internet. Mereka juga
disebut penelitian Internet, [1] Ilmu Internet [2]
atau iScience atau metode berbasis Web. [3] Metode penelitian online seperti jurnal terkait dengan metode penelitian yang ada, kompleksitas dan peluang telah mencapai tingkatan baru. Memasukkan penelitian media sosial dapat memberikan wawasan unik tentang konsumen dan segmentasi sosial, dan dapat memperoleh penilaian "emosional" orang berdasarkan pertanyaan yang menarik.

\section{A. Pendidikan Kewarganegaraan}

Secara bahasa, istilah Civic Education menurut beberapa ahli menerjemahkan kedalam bahasa Indonesia menjadi Pendidikan Kewargaan dan Pendidikan Kewarganegaraan. Menurut Kerr (Winataputra dan Budimansyah, 2012) bahwa Citizenship education or civics education didefinisikan sebagai berikut: Citizenship or civics education is construed broadly to encompass the preparation of young people for their roles and responsibilities as citizens and, in particular, the role of education (trough schooling, teaching, and learning) in that preparatory process. Maksud pendapat Kerr yaitu kewarganegaraan umumnya mencakup proses mempersiapkan generasi muda untuk mengambil peran dan tanggung jawab sebagai warga negara. Sedangkan secara khusus, peran pendidikan meliputi pendidikan sekolah, proses belajar mengajar, dalam proses mempersiapkanwarga negara tersebut.

Menurut Cogan (1999) mengemukakan Civic Education yaitu sebagai "the foundational course work in school designed to prepare young citizens for an active role in their communities in their adult lives". Maksudnya yaitu mata pelajaran dasar di sekolah yang dirancang untuk mempersiapkan warga negara muda agar setelah dewasa dapat berperan aktif dalam masyarakat.

Oleh karena itu dapat, dikatakan bahwa Pendidikan Kewarganegaraan atau Civic Education merupakan suatu pendidikan/ rencana pembelajaran yang berupaya memanusiakan (humanizing), membudayakan (civilizing) dan memberdayakan (empowering) umat manusia dalam hal ini peserta didik, diri sendiri dan kehidupannya menjadi warga negara yang baik sebagaimana tuntutan keharusan/ yuridis konstritusional bangsa/ negara yang bersangkutan.

Dapat disimpulkan bahwa dilahirkannya Pendidikan Kewarganegaraan bertujuan untuk memberikan tameng bagi suatu negara untuk mencegah pengaruh buruk atau negatif yang dapat merugikan negara itu sendiri. Kemudian bagi bangsa Indonesia lahirnya Pendidikan Kewarganegaraan bertujuan untuk membentuk warga negara yang cerdas, terampil dan berkarakter yang setia kepada bangsa dan negara Indonesia dengan merefleksikan berfikir dan bertindak sesuai dengan amanat pancasila dan Undang-Undang Dasar 1945 tetap menjaga negara ini, kalaupun ada penyerangan dari luar, penyerangan tersebut dapat dicegah dengan nilai moral yang ada pada pendiidkan kewarganegaraan itu sendiri.

\section{B. Nasionalisme}

Nation yaitu berasal dari bahasa latin Natio, yang dikembangkan dari kata Nascor 
(saya dilahirkan), sehingga pada awalnya Nation (bangsa) dimaknai dengan "Sekelompok orang yang dilahirkan di suatu daerah yang sama" (group of people born in the same place). Istilah kata "Nasionalisme" oleh Abbe Barruel pertama kali digunakan di Jerman pada abad ke-15. terhadap bangsa/ suku asalnya. Nasionalisme pada awalnya terkait dengan kecintaan masyarakat terhadap bangsa, bahasa, dan daerah asal. Rasa cinta tersebut disebut dangan semangat patriotisme. Oleh karena itu, nasionalisme dan patriotisme memiliki makna yang sama pada awalnya.

Nasionalisme merupakan sikap politik dengan budaya dan wilayah yang sama, cita-cita dan tujuan yang sama, sehingga masyarakat bangsa ini memiliki kesetiaan yang mendalam terhadap bangsa itu sendiri. Menurut beberapa para ahli bahwa nasionalisme yaitu kecintaan alamiah terhadap air dan tanah yang dapat menimbulkan kesadaran masyarakat dan mendorong mereka untuk menegakkan kedaulatan, serta bersepakat mendirikan negara berdasarkan kebangsaan yang telah disepakati, serta bersedia mengorbankan untuk kepentingan bangsa dan negara.

Untuk meningkatkan jiwa nasionalisme generasi milenial maka perlu dilaksanakan pendidikan karakter melalui pengajaran Pendidikan kewarganegaraan di sekolah dan perguruan tinggi. Dengan menanamkan nilainilai luhur bangsa Indonesia, dan menanamkan jiwa nasionalisme dikalangan generasi milenial harapan bangsa dan negara, menanamkan nilainilai luhur Pancasila dan makna UndangUndang Dasar 1945, dan menanamkan rasa cinta tanah air dan bangsa, meningkatkan jiwa nasionalisme yang tinggi dan mencintai produk Indonesia. Pada saat ini, dalam rangka meningkatkan moralitas generasi milenial harapan bangsa untuk meningkatkan semangat nasionalisme, maka permasalahan yang harus diselesaikan adalah membentuk mentalitas generasi milenial yang mencintai negerinya dan rela berkorban demi bangsa dan negaranya. Krisis multidimensi yang dihadapi negara Indonesia saat ini, ditambah dengan krisis ekonomi, dapat dengan mudah menimbulkan konflik antar negara. Hal ini terjadi karena
Istilah ter sebut dirancang untuk mahasiswa dari daerah yang sama atau berbahasa yang sama, sehingga mereka (di kampus yang baru dan di daerah baru) terus menunjukkan rasa cinta mereka

faktor keterpurukan dan kegoncangan psikologis masyarakat Indonesia. Oleh karena itu, perlu ditanamkan kecintaan pada tanah air dan bangsa pada generasi milenial warga negara Indonesia, melalui Pendidikan Kewarganegaraan dilingkungan sekolah dan Perguruan Tinggi.

\section{HASIL PENELITIAN DAN PEMBAHASAN}

1. 1. Pengaruh Era Globalisasi terhadap Jiwa Nasionalisme Generasi Milenial

Di Era Globalisasi dengan ciri-ciri keterbukaan dan ketergantungan antar negara membuat negara tidak mengenal batasbatasnya. Akibat saling keterbukaan dan ketergantungan dengan arus informasi dan telekomunikasi dalam waktu dekat persaingan internasional akan semakin ketat, terutama pada bidang ekonomi. Khusus untuk Indonesia, globalisasi semacam ini tidak hanya ditujukan untuk kepentingan dalam negeri, tapi juga untuk kepentingan global. Selain itu, dari segi keuntungan domestik, pengaruh globalisasi ini dapat memberikan pola pikir global dan perilaku kompetitif kepada masyarakat,suka bekerja keras, memiliki etos kerja, berkreasi serta mau belajar dan berkembang untuk meningkatkan keterampilan dan kinerja kerja.

Pengaruh globalisasi terhadap jiwa nasionalisme generasi milenial merupakan tatanan masyarakat global yang tiada habisnya. Globalisasi merupakan salah satu faktor yang dapat berdampak positif dan negatif bagi perkembangan generasi milenial Indonesia.

Globalisasi pada hakikatnya merupakan proses pengusulan ide yang kemudian diikuti oleh negara lain, negaranegara tersebut akhirnya mencapai kesepakatan bersama dan menjadi pedoman 
bersama bagi negara-negara di dunia. Globalisasi terjadi di semua bidang kehidupan, seperti ideologi, politik, ekonomi, sosial budaya, pertahanan negara dan keamanan. Dalam era globalisasi saat ini, perkembangan ilmu pengetahuan dan teknologi informasi memegang peranan penting. Arus globalisasi yang dengan cepat memasuki masyarakat Indonesia, tentu sangat berpengaruh di kalangan generasi milenial. Sebagai proses globalisasi terjadi dalam dua dimensi interaksi antar negara, yaitu dimensi ruang dan waktu. Ruang semakin berkurang, waktu semakin dipersingkat dalan interaksi dan komunikasi skala dunia.

Globalisasi terjadi di semua bidang kehidupan, seperti politik, ekonomi, sosial budaya, pertahanan negara, keamanan dan lain-lain. Selain itu, perkembangan teknologi dan komunikasi yang pesat menjadi faktor pendukung utama perkembangan globalisasi. Adanya globalisasi telah sangat mempengaruhi kehidupan suatu negara termasuk Indonesia. Globalisasi juga mempengaruhi berbagai bidang. Dari perspektif bidang politik, globalisasi sangat berpengaruh pada sektor pemerintahan. Pemerintahan berjalan secara terbuka dan demokratis. Jika pemerintah dijalankan secara jujur dan demokratis pasti akan berdampak positif bagi perkembangan suatu negara, namun jika terjadi sebaliknya pasti akan menimbulkan konflik dalam kehidupan berbangsa dan bernegara.

Jika dilihat dari bidang ekonomi di era pasar bebas saat ini yang artinya terbukanya pasar internasional yang dapat memberikan kesempatan kerja yang tentunya akan meningkatkan devisa negara. Di bidang sosial dan budaya, globalisasi terikat untuk memungkinkan generasi milenial Indonesia berkembang dengan cara berpikir yang baik, dan meningkatkan etos kerja yang tinggi, dengan meniru negara-negara maju. Seiring kemajuan suatu bangsa akan meningkatkan rasa nasionalisme suatu bangsa.

Selain perkembangan yang positif, globalisasi juga dapat berdampak negatif, bahkan berdampak pada keutuhan suatu bangsa dan negara. Hal ini dapat dilihat dari berbagai segi, antara lain :

1) Globalisasi dapat membuat masyarakat Indonesia percaya bahwa liberalisme dapat membawa kemajuan dan kemakmuran, hal ini jika dibiarkan akan berdampak pada pemahaman generasi milenial terhadap ideologi bangsa, dan akan meyebabkan kurangnya rasa nasionalisme dikalangan generasi milenial Indonesia.

2) Di bidang ekonomi, pengaruh globalisasi bagi bangsa Indonesia, khususnya generasi milenial adalah berkurangnya rasa cinta pada produk dalam negeri sendiri, mereka lebih bangga menggunakan atau membeli produk dari negara lain dari pada produk negaranya sendiri.

3) Globalisasi juga mempengaruhi kesenjangan sosial antar masyarakat, yang kaya akan semakin kaya dan yang miskin akan semakin terpuruk.

4) Generasi milenial bangsa Indonesia banyak meniru gaya kebaratbaratan, dan melupakan jati dirinya sebagai bangsa Indonesia

Sikap individualisme yang tinggi di karalangan masyarakat Indonesia, terutama generasi milenial, seperti ketidakpedulian terhadap orang lain. Jika semua ini dibiarkan, menyebabkan krisis moral bagi generasi milenial, bahkan dapat menimbulkan perilaku anarkis di kalangan rekan senegara Indonesia Untuk meningkatkan jiwa nasionalisme generasi milenial maka perlu dilaksanakan pendidikan karakter melalui pengajaran pendidikan kewarganegaraan di sekolah dan perguruan tinggi. Dengan menanamkan nilai- 
nilai luhur bangsa Indonesia, dan menanamkan jiwa nasionalisme dikalangan generasi milenial harapan bangsa dan negara, menanamkan nilainilai luhur Pancasila dan makna UndangUndang Dasar 1945, dan menanamkan rasa cinta tanah air dan bangsa, meningkatkan jiwa nasionalisme yang tinggi dan mencintai produk Indonesia. Pada saat ini, dalam rangka meningkatkan moralitas generasi milenial harapan bangsa untuk meningkatkan semangat nasionalisme, maka permasalahan yang harus diselesaikan adalah membentuk mentalitas generasi milenial yang mencintai negerinya dan rela berkorban demi bangsa dan negaranya. Krisis multidimensi yang dihadapi negara Indonesia saat ini, ditambah dengan krisis ekonomi, dapat dengan mudah menimbulkan konflik antarnegara. Hal ini terjadi karena faktor keterpurukan dan kegoncangan psikologis masyarakat Indonesia.

Oleh karena itu, perlu ditanamkan kecintaan pada tanah air dan bangsa pada generasi milenial warga negara Indonesia, melalui Pendidikan Kewarganegaraan dilingkungan sekolah dan Perguruan Tinggi.

\section{Pentingnya Pendidikan Kewarganegaraan}

Pendidikan

Kewarganegaraan bertujuan untuk menanamkan semacam rasa nasionalisme dan nilai-nilai moral kebangsaan bagi para generasi muda. Pendidikan ini menjadi tolak ukur dalam menjalankan kewajiban dan memperoleh hak warga negara, guna menjaga kejayaan dan kemuliaan bangsa. Diharapkan melalui Pendidikan kewarganegraan ini, generasi milenial memiliki pemahaman yang utuh tentang demokrasi dan Hak Asasi Manusia (HAM). Dengan pemahaman tersebut, mereka dengan damai dan bijaksana akan memberikan kontribusi yang berarti untuk mengatasi berbagai masalah yang dihadapi negara, seperti konflik dan kekerasan yang terjadi di Indonesia dengan cara-cara yang damai dan cerdas.

Membina generasi milenial yang bertanggung jawab atas keamanan dan kejayaan nasional. Rasa tanggung jawab ini akan tercermin dari partisipasi aktif generasi milenial dalam pembangunan. Generasi milenial bertanggung jawab akan menyaring pengaruh luar, mengambil sisi positif dan menolak hal-hal yang bertentangan dengan nilai-nilai luhur dan moral bangsa.

Pendidikan Kewarganegaraan mengajarkan warga negara bagaimana untuk tidak hanya tunduk dan patuh pada negara, tetapi juga mengajari warga negara yang harus toleran dan mandiri. Pendidikan seperti ini memberikan pengetahuan bagi generasi masa depan, pengembangan keahlian, dan pengembangan karakter publik. Pengembangan komunikasi dengan lingkungan yang lebih luas dalam pendidikan kewarganegaraan. Meskipun pengembangan tersebut bisa belajar tanpa menempuh pendidikan kewarganegaraan, namun akan lebih baik jika pendidikan dimanfaatkan seluas mungkin untuk pengembangan diri. Rasa kewarganegaraan yang tinggi akan membuat kita tidak mudah tertarik dengan kejayaan yang sifatnya hanya sementara. Selain itu, kita tidak akan mudah terpengaruh secara langsung budaya yang bukan dari Indonesia dan menghormati semua budaya dan nilai-nilai yang berlaku di negara. Pendidikan kewarganegaraan pada hakikatnya merupakan salah satu bentuk pendidikan untuk generasi penerus, yang bertujuan agar mereka menjadi warga negara yang memiliki pemikiran yang tajam dan sadar akan arus dan kewajiban kehidupannya bermasyarakat dan berbangsa, serta untuk membangun ketahanan seluruh warga negara menjadi warga dunia (global society).

Pembelajaran Pendidikan

Kewarganegaraan dapat dicapai melalui perencanaan dan pelaksanaan yang baik, pembelajaran berdasarkan tujuan pendidikan dan pemantauan pembelajaran melalui evaluasi, sehingga tujuan dari pembelajaran pendidikan kewarganegaraan dapat tercapai dengan tepat, dan dapat membentuk warga 
negara yang sadar akan hak dan kewajibannya sebagai bagian dari Negara Kesatuan Republik Indonesia (NKRI) dan merdeka, hal ini tidak akan membebani siapapun, yang berpartisipasi dalam kegiatan belajar, memahami sejarah, cita-cita dan tujuan negara dan mengedepankan kemajuan dalam ketertiban, keamanan, perekonomian, dan kesejahteraan umum. Dengan demikian, kualitas pelaksanaan pendidikan kewarganegaraan akan semakin baik meningkatkan kesadaran mahasiswa sebagai bagian dari warga negara Indonesia generasi milenial penerus bangsa.

Pendidikan mempunyai peran besar dalam mencapai perubahannya pada diri warga negara. Melalui pendidikan, dapat dibentuk kondisi mental yanng lebih baik untuk dibentuk kebangkitan moral-spiritual yang perlu dikembangkan. Demikian pula penguasaan ilmu pengetahuan dan teknologi dapat diusahakan melalui pendidikan yang benar. Namun, harus diakui bahwa hasil dari proses pendidikan baru terasa setelah melewati satu generasi. Pendidikan harus disertai dengan terbentuknya kepemimpinan yang mampu melakukan proses perubahan sejak sekarang. Bahkan kepemimpinan sangat penting untuk mewujudkan proses pendidikan yang diperlukan.

Proses pendidikan meliputi banyak segi, dan setiap aktivitas manusia mengandung unsur pendidikan. namun secara umum pendidikan dapat mencakup suatu sistem pendidikan sekolah dan pendidikan luar sekolah. Kedua hal tersebut harus saling mendukung untuk mencapai hasil yang terbaik. Dalam pendidikan di luar sekolah yang amat besar perannya yaitu lingkungan keluarga. Sebab manusia lahir dan tumbuh di lingkungan keluarga. Hal ini sangat jelas dalam globalisasi yang membuat setiap unsur masyarakat makin intensif pengembangan karakter publik. Pengembangan komunikasi dengan lingkungan yang lebih luas dalam pendidikan kewarganegaraan. Meskipun pengembangan tersebut bisa belajar tanpa menempuh pendidikan kewarganegaraan, namun akan lebih baik jika pendidikan dimanfaatkan seluas mungkin untuk pengembangan diri. Rasa kewarganegaraan yang tinggi akan membuat kita tidak mudah tertarik dengan kejayaan yang sifatnya hanya sementara. Selain itu, kita tidak akan mudah terpengaruh secara langsung budaya yang bukan dari Indonesia dan menghormati semua budaya dan nilai-nilai yang berlaku di negara. Pendidikan kewarganegaraan pada hakikatnya merupakan salah satu bentuk pendidikan untuk generasi penerus, yang bertujuan agar mereka menjadi warga negara yang memiliki pemikiran yang tajam dan sadar akan arus dan kewajiban kehidupannya bermasyarakat dan berbangsa, serta untuk membangun ketahanan seluruh warga negara menjadi warga dunia (global society).

Pembelajaran Pendidikan Kewarganegaraan dapat dicapai melalui perencanaan dan pelaksanaan yang baik, pembelajaran berdasarkan tujuan pendidikan dan pemantauan pembelajaran melalui evaluasi, sehingga tujuan dari pembelajaran pendidikan kewarganegaraan dapat tercapai dengan tepat, dan dapat membentuk warga negara yang sadar akan hak dan kewajibannya sebagai bagian dari Negara Kesatuan Republik Indonesia (NKRI) dan merdeka, hal ini tidak akan membebani siapapun, yang berpartisipasi dalam kegiatan belajar, memahami sejarah, cita-cita dan tujuan negara dan mengedepankan kemajuan dalam ketertiban, keamanan, perekonomian, dan kesejahteraan umum. Dengan demikian, kualitas pelaksanaan pendidikan kewarganegaraan akan semakin baik meningkatkan kesadaran mahasiswa sebagai bagian dari warga negara Indonesia generasi milenial penerus bangsa.

Pendidikan mempunyai peran besar dalam mencapai perubahannya pada diri warga negara. Melalui pendidikan, dapat dibentuk kondisi mental yanng lebih baik untuk dibentuk kebangkitan moral-spiritual yang perlu dikembangkan. Demikian pula penguasaan 
ilmu pengetahuan dan teknologi dapat diusahakan melalui pendidikan yang benar. Namun, harus diakui bahwa hasil dari proses pendidikan baru terasa setelah melewati satu generasi. Pendidikan harus disertai dengan terbentuknya kepemimpinan yang mampu melakukan proses perubahan sejak sekarang. Bahkan kepemimpinan sangat penting untuk mewujudkan proses pendidikan yang diperlukan.

Proses pendidikan meliputi banyak segi, dan setiap aktivitas manusia mengandung unsur pendidikan. namun secara umum pendidikan dapat mencakup suatu sistem pendidikan sekolah dan pendidikan luar sekolah. Kedua hal tersebut harus saling mendukung untuk mencapai hasil yang terbaik. Dalam pendidikan di luar sekolah yang amat besar perannya yaitu lingkungan keluarga. Sebab manusia lahir dan tumbuh di lingkungan keluarga. Hal ini sangat jelas dalam globalisasi yang membuat setiap unsur masyarakat makin intensif hubungannya dengan unsur masyarakat lainnya, demikian pula dengan unsur masyarakat luar negeri.

\section{Paradigma Pendidikan Kewarganegaraan}

Dalam hal ini, Tilaar (2005:14) meyakini bahwa semakin banyak pihak yang peduli dan bekerja keras mengupayakan pembentukan bangsa Indonesia menjadi religius, beriman, bertaqwa, dan berbudi pekerti yang luhur semakin lebih baik adanya. Negara, dalam kasus ini tidak menyangkut urusan pribadi, tapi menyangkut sosial, yakni sebatas tegaknya social fairness dalam pelaksanaan pengajaran pendidikan Kewarganegaraan di sekolah, demi kenyamanan kehidupan bersama antar warga negara.

Mengingat pentingnya pembangunan karakter generasi milenial, meskipun pendidikan kewarganegaraan sudah dilakukan oleh keluarga dan masyarakat, namun akan lebih baik dilakukan di sekolah juga. Yang menjadi permasalahan adalah paradigma pendidikan kewarganegaraan seperti apa yang sedang dikembangkan di sekolah-sekolah saat ini. Perlaku moral siswa masih sangat mengecewakan, sering tejadi keretakan dan ketegangan sosial bernuansa pendidikan kewarganegaraan, maraknya fenomena kemerosotan moral masyarakat, menunjukkan bahwa ada masalah serius dalam mempelajari pendidikan kewarganegaraan di sekolahsekolah. Pendidikan kewarganegaraan di sekolah masih jauh dari peran penting membangun moral bangsa. Kesalahpahaman tentang pendidikan kewarganegaraan juga menyebabkan menyempitnya ruang kesenjangan hidup pendidikan kewarganegaraan di sekolah.

Berdasarkan dimensi tersebut, maka aspek-aspek Pendidikan kewarganegaraan di sekolah haruslah dengan urutan skala prioritas dan garapan materi pendidikan kewarganegaraan sebagai berikut: Pertama, pendidikan Kewarganegaraan harus memprioritaskan dimensi konsekuensial berpendidikan kewarganegaraan. Mengajak dan melatih peserta didik untuk mempraktikan nilai-nilai PKn dalam kehidupan nyata di masyarakat, seperti menjaga kebersihan, bertindak jujur dalam ujian, membantu orang lain, menghormati orang lain, dan lain-lain. Melatih peserta didik untuk menyisihkan uang jajannya untuk disumbangkan kepada fakir miskin. Mengajak peserta didik untuk mengunjungi orang lain dan melakukan kegiatan bersama untuk membangun sikap nasionalisme, rasa hormat, toleransi dan kerjasama antar warga negara. Mengajarkan bahwa pendidikan kewarganegaraan adalah rahmat bagi kehidupan bersama. Pendidikan Kewarganegaraan harus menjadi faktor perekat, bukan faktor disintegrasi, faktor solusi, bukan faktor masalah. Karena semua warga negara menginginkan kedamaian, sejahtera dan kehidupan warga negara yang berkualitas. Peserta didik penting disadarkan bahwa berpendidikan kewarganegaraan harus menghasilkan perilaku yang baik. Kedua, 
dimensi eksperensial digarap dengan upayaupaya dengan kesadaran peserta didik setiap saat dalam kekaguman pada keindahan, kedahsyatan dan kecanggihan alam semesta yang diciptakan Tuhan dan dalam aktivitas peserta didik sehari-hari.

Ketiga, pengolahan dimensi ideologis dengan tetap mengedepankan sikap nasionalisme. Keyakinan pada kebenaran yang di pahami peserta didik tidak boleh mengarah pada fanatisme sempit, arogansi religius, kelumpuhan akal dan sikap anti dialog. Tanpa kesadaran ini orang mudah tergoda untuk pergi mengambil tindakan lain penyelamatan keresahan sosial.

Proses pendidikan meliputi banyak segi, dan setiap kegiatan manusia mengandung unsur pendidikan. Namun secara umum dapat dikatakan bahwa pendidikan meliputi sistem sekolah dan pendidikan luar sekolah. Dua hal itu harus saling mendukung untuk mencapai hasil yang optimal. Dalam pendidikan luar sekolah yang amat besar perannya adalah pendidikan di lingkungan keluarga. Sebab di lingkungan keluarga manusia lahir dan tumbuh di masa yang paling menentukan bagi pembentukan kepribadiannya. Hal ini terutama terasa dalam globalisasi yang membuat setiap unsur masyarakat makin intensif hubungannya dengan unsur masyarakat lainnya, demikian pula dengan unsur masyarakat luar negeri. Hubungan itu dapat berupa kerjasama atau persaingan yang dalam globalisasi makin intensif kondisinya. Akibatnya adalah bahwa tidak cukup hanya sebagian kecil masyarakat bermutu tinggi untuk mencapai kemajuan satu bangsa atau satu warga negara. Harus sebanyak mungkin warga masyarakat mempunyai mutu tinggi untuk dapat melakukan kerjasama dan persaingan bangsa dan warga negara (Hafidh and Anwar 2016).

Pembelajaran

Pendidikan

Kewarganegaraan masih berorientasi pada Transfer of knowledge dari masayrakat ke masyarakat dan pendekatan ekspositori masih mendominasi yang menyebabkan terabaikannya pendekatan inquiri, pemecahan masalah dan rendahnya keterlibatan masyarakat dalam pelaksanaan dan perencanaan pembelajaran sehingga muncul budaya belajar menghapal hal ini disebabkan oleh rendahnya motivasi mengajar pendidik karena menyangkut kemampuan aspek kompetensi pendidik yang dimiliki (Halimah 2018).

Generasi emas tahun 2045 merupakan harapan masa depan bangsa Indonesia. Pendidikan merupakan media yang sangat sentral dalam mempersiapkan generasi emas terutama karakternya.Karakter yang harus dibangun haruslah bersifat holistik dan komprehensif berbasis pancasilais.Pendidikan tidak hanya mentransfer ilmu tetapi juga nilainilai terutama karakter.Karakter yang ditanamkan pada diri generasi emas haruslah berbasis tiga aspek yakni nilai kejujuran, nilai kebenaran dan nilai keadilan. Nilai-nilai tersebut sangat bersesuaian dengan nilai-nilai Pancasila yang sangat mengedepankan nilai kejujuran, kebenaran dan keadilan dalam hidup dan kehidupan generasi emas.Proses pendidikan berbasis nilai kejujuran, kebenaran dan keadilan adalah proses pendidikan yang memanusiakan manusia. Penanaman nilai-nilai tersebut akan melahirkan generasi emas yang berkarakter Pancasilais berbasis budaya nasional Indonesia(Abi 2017) .

Adapun generasi Alpha dalam kesehariannya tidak lepas dari penggunaan gadget, sehingga mempengaruhi mereka dalam aktifitas seharihari seperti gaya belajar, hubungan social, dan karakter. Untuk itu lingkungan keluarga, sekolah, dan masyarakat memiliki peranan penting dalam mendidik generasi alpha. Prioritas utama dalam pendidikan bagi generasi alpha adalah penguatan karakter. Salah satu nilai karakter yang penting di tanamkan bagi generasi alpha di era digital adalah penguatan nilai nasionalisme (Apriani and Sari 2020).

Tantangan yang dihadapi dalam proses penanaman nilai-nilai Pancasila pada era 
revolusi industri 4.0 saat ini yaitu salah satunya terletak pada peserta didik yang sudah tidak dapat terlepas dari Handphone dan Gadjet. Mereka dengan mudah mendapatkan informasi-informasi dari luar melalui internet yang terkadang informasi tersebut tidak sesuai dengan nilai-nilai Pancasila. Namun hal tersebut juga dapat diatasi dengan cara memanfaatkan perkembangan informasi serta Ilmu Pengetahuan dan Teknologi (IPTEK) menjadi media dalam penanaman dan penguatan Pancasila di era revolusi industri 4.0 (A. S. Lestari, Aini, and Z. 2019).

Maka dari itu perlu diadakan tentang penegasan dan mengembalikan kedudukan Pancasila sebagai dasar negara, dan ini merupakan hal yang sangat penting karena sudah terlalu banyak terjadi kesalahan penafsiran tentang Pancasila sebagai dasar negara. Dan penafsiran itu menyatakan bahwa Pancasila bukan hanya sebagai dasar negara tetapi Pancasila sebagai alat kekuasaan yang dapat mengendalikan semua apapun yang dilakukan negara Indonesia. Sebagai nilai yang bersifat abstrak, Pancasila harus bersifat konkrit dan upaya agar menjadi konkrit adalah dengan menjadikan nilai-nilai dasar Pancasila sebagai norma dasar dan sumber normatif bagi penyusunan hukum negara Indonesia yang positif bagi negara.

Menerapkan Pancasila dalam kehidupan dan perilaku sehari-hari, salah satu kedudukan Pancasila bagi bangsa Indonesia adalah sebagai pandangan hidup berbangsa. Yakni mengandung pengertian bahwa nilainilai Pancasila merupakan pegangan dalam mengatur sikap dan tingkah laku yang menjadi pedoman. Bangsa Indonesia harus menghayati dan mengamalkan nilai-nilai kebenarannya. Jika tidak diamalkan maka pandangan hidup tersebut tidak bermanfaat sama sekali dalam kehidupan sehari-hari. Dalam keadaan tersebut, bangsa Indonesia akan mudah dimanfaatkan pihak-pihak tertentu sehingga terjadi perpecahan (Anggraini et al. 2020).

Untuk membangun integritas bangsa dikalangan pemuda perlu diterapkan nilai-nilai nasionalisme dan patriotisme kepada generasi muda atau pemuda perlu di lakukan sejak dini agar nilai-nilai tersebut sungguh-sungguh dihayati dan diamalkan oleh segenap warga Negara baik dalam kehidupan pribadi maupun dalam kehidupan sosial (Suwito 2014).

Untuk menjadi bangsa yang besar, bangsa Indonesia harus menanamkan sikap nasionalisme sejak dini, sejak kecil, atausejak masa sekolah dasar. Karena jika sikap nasionalisme terlambat diimplementasikan kepada bangsa Indonesia, bangsa Indonesia telah kehilangan generasi muda yang rendahakan sikap nasionalisme. Maka untuk menanggulangi masalah tersebut danuntuk menambah rasa nasionalisme bangsa Indonesia adalah dengan dilatih tentangsikap-sikap yang baik sesuai dengan nilai-nilai dari Pancasila, tidak mengajarkanhal-hal yang melanggar nilai-nilaiPancasila, menanamkan rasa cinta tanahair sejak dini, melestarikan budaya Bangsa Indonesia, dan memberi penyuluhankepada seluruh bangsa Indonesia akan pentingnya nasionalisme terhadap masadepan bangsa Indonesia (E. Y. Lestari, Janah, and Wardanai 2019), dan ebagai bangsa dan negara ditengah bangsa lain di dunia membutuhkan intentitas kebangsaan (nasionalisme) yang tinggi dari generasi muda Indonesia, seperti: memiliki kemampuan untuk mengambil sikap yang bertanggung jawab sesuai dengan hati nuraninya, memiliki kemampuan untuk mengenali masalah hidup dan kesejahteraan serta cara-cara pemecahannya, dan memiliki kemampuan untuk memaknai peristiwa sejarah dan nilainilai budaya bangsa untuk menggalang persatuan Indonesia. Semangat nasionalisme dibutuhkan tetap eksisnya bangsa dan negara Indonesia. Nasionalisme yang tinggi dari generasi muda sehingga akan membuat perilaku positif dan terbaik untuk bangsa dan negara. Dalam dekade terakhirnya, ada kecenderungan menipisnya jiwa nasionalisme dikalangan generasi muda (Widiyono 2019). 


\section{SIMPULAN}

Pendidikan Kewarganegaraan bagi bangsa Indonesia yaitu guna membentuk bangsa Indoenesia seutuhnya, yaitu seperti amanat pembukaan Undang-Undang Dasar 1945, yaitu mewujudkan lingkungan di sekitar bangsa Indonesia yang beragama, berkemanusiaan, dan beradab, yang berkerakyatan dan adil terhadap lingkungan sekitar. Dalam era globalisasi saat ini, bangsa Indonesia menghadapi berbagai tantangan yang berdampak pada moralitas bangsa, khususnya generasi milenial penerus bangsa. Hal ini jika dibiarkan akan mampu mencairkan jiwa nasionalisme di kalangan generasi milenial. Nasionalisme merupakan perasaan cinta tanah air, kesepakataan untuk mendorong rakyat menegakkan kedaulatan, dan kesepakatan membentuk negara berdasarkan kebangsaan, juga dijadikan pijakan pertama dan tujuan kegiatan budaya dan ekonomi.

Pendidikan

Kewarganegaraan mengajarkan warga negara bagaimana untuk tidak hanya tunduk dan patuh pada negara, tetapi juga mengajari warga negara yang harus toleran dan mandiri. Pendidikan seperti ini memberikan pengetahuan bagi generasi masa depan, pengembangan keahlian, dan pengembangan karakter publik.

Cara mengatasi pengaruh globalisasi terhadap jiwa nasionalisme adalah dengan membekali pemahaman dan pengetahuan tentang nasionalisme pada generasi milenial, sehingga mampu membentuk mentalitas dikalangan generasi milenial, agar menjadi generasi milenial yang memiliki kepribadian, memiliki rasa cinta tanah air bangsa dan negara, dan rela berkorban bagi bangsa dan negara Indonesia.

\section{DAFTAR PUSTAKA}

Abi, Antonius Remigius. 2017. "Paradigma Membangun Generasi Emas Indonesia
Tahun 2045." Jurnal Ilmiah Pendidikan

Pancasila dan Kewarganegaraan 2(2): 89.

Anggraini, Devi, Fauzal Fathari, Jordi Wahyu Anggara, and Muhammad Devon Ardi Al Amin. 2020. "Pengamalan Nilai-Nilai Pancasila Bagi Generasi Milenial." Jurnal Inovasi Ilmu Sosial dan Politik 2(1): 16.

Apriani, An-Nisa, and Indah Perdana Sari. 2020.

"Penguatan Karakter Nasionalisme Generasi Alphamelalui Living Values Education Program (LVEP)." LITERASI (Jurnal Ilmu Pendidikan) XI(2): 77

Anthony D Smith. 1998. Nasionalism and Modernism: A Critical Survey Of RecentTheories Of Nations and Nationalism.

Budimansyah, D dan Winataputra. (2007). Civic Education 'Konteks,Landasan,. Bahan Ajar, Dan Kultur Kelas. Bandung

Cogan, J. J. (1999). Developing the civic Society : The Role of Civic Education. Bandung Darmiyanti, Tri. 2011. "Pengaruh Globalisasi terhadap nilai-nilai nasionalisme".Jakarta Djahiri, K. Pendidikan nilai moral dalam dimensi pendidikan kewarganegaraan. Bandung: Laboratorium PKn FPIPS UPI. 2006

Dj iwandono, J. Soedjati. 2000. “Globalisasi dan Pendidikan Nilai" dalam Sindhunata (Ed),Menggagas Paradigma Baru Pendidikan: Demokratisasi, Otonomi, Civil Society, Globalisasi.Yogyakarta: Kanisiu

Hafidh, Maksum, and Faisal Anwar. 2016. "Peran Pendidikan Kewarganegaraan Di Era Globalisasi Dalam Menumbuhkan Semangat Nasionalisme." 5(2): 9-10.

Halimah, Lili. 2018. "Pengaruh Pembelajaran Pendidikan Kewarganegaraan Terhadap Nasionalisme Peserta Didik Sekolah Menengah Kota Cimahi." Pedagogia: Jurnal Ilmu Pendidikan PENGARUH 16(3): 215

Kaelan. (2010). Pendidikan Kewarganegaraan. Yogyakarta: Paradigma

Kohn, Hans.1984.Nasionalisme Arti dan Sejarahnya. Jakarta: Erlangga

Lestari, Aisyah Sri, Munifa Aini, and Anis Fuadah Z. 2019. "KIPRAH GENERASI MILENIAL PADA ERA 4.0 DALAM MEMBUMIKAN PANCASILA." attadib journal of elementary Education 3(2): 19.

Lestari, Eta Yuni, Miftahul Janah, and Putri Karima Wardanai. 2019. "Menumbuhkan 
Kesadaran Nasionalisme Generasi Muda Di Era Globalisasi Melalui Penerapan NilaiNilai Pancasila." Adil Indonesia Jurnal 1(1): 26.

Suwito, Anton. 2014. "Membangun Integritas Bangsa Di Kalangan Pemuda Untuk Menangkal Radikalisme.” Jurnal Ilmiah CIVIS IV(2): 586.

Widiyono, S. 2019. "Pengembangan Nasionalisme Generasi Muda Di Era Globalisasi S.” Jurnal Populika 7(1): 20. 